Article

\title{
Linkage between Leaders' Behaviour in Performance Management, Organisational Justice and Work Engagement in Public Sector
}

\author{
Živilè Stankevičiūtė *(i) and Asta Savanevičienė (1) \\ School of Economics and Business, Kaunas University of Technology, Gedimino g. 50, LT-44249 Kaunas, \\ Lithuania; asta.savaneviciene@ktu.lt \\ * Correspondence: zivile.stankeviciute@ktu.lt; Tel.: +370-650-11505
}

check for

updates

Citation: Stankevičiūtè, Živilè, and Asta Savanevičienè. 2021. Linkage between Leaders' Behaviour in Performance Management, Organisational Justice and Work Engagement in Public Sector. Economies 9: 15. https://doi.org/ 10.3390/economies 9010015

Academic Editor:

Wadim Strielkowski

Received: 30 December 2020

Accepted: 28 January 2021

Published: 3 February 2021

Publisher's Note: MDPI stays neutral with regard to jurisdictional claims in published maps and institutional affiliations.

Copyright: (C) 2021 by the authors Licensee MDPI, Basel, Switzerland. This article is an open access article distributed under the terms and conditions of the Creative Commons Attribution (CC BY) license (https:/ / creativecommons.org/licenses/by/ $4.0 /)$.

\begin{abstract}
In the last decade, leaders' behaviour in performance management has been gaining increasing attention, arguing that it is beneficial in terms of improved employee attitudes, behaviour, and performance in the public sector. However, empirical support for such claim is still scant. Given the relevance of work engagement and organisational justice in the public sector and acknowledging a worldwide employee engagement crisis, the paper aims at revealing the linkage between leaders' behaviour in performance management, organisational justice, and employee engagement in the public sector. In doing this, quantitative data were collected in a survey from employees working in the public sector in Lithuania (299 responses). The findings showed that goal setting and feedback had a significant and positive effect on employee engagement, supporting the theoretical notion that leaders' behaviour in performance management was crucial in engaging people. As it was expected, goal setting and feedback had a positive effect on organisational justice; meanwhile, organisational justice significantly and positively predicted employee engagement. Turning to the mechanism by which leaders' behaviour influences work engagement, it seems that organisational justice partly mediated the relationships between goal setting and employee engagement and fully mediated the relationships between feedback and work engagement. These findings affirm that public sector should strive for improving the leaders' behaviour in performance management as it in turn might impact overall organisational performance.
\end{abstract}

Keywords: performance management; leaders' behaviour; goal setting; feedback; work engagement; organisational justice; public sector

\section{Introduction}

Responding to the call of the politicians and citizens to demonstrate the effectiveness and impact on complex problems (Blackman et al. 2012), the public sector has been a subject of transformation for a couple of decades (De Vries and Nemec 2013; Teeroovengadum et al. 2019). With the aim to underpin the crises of confidence in the public sector (Osborne and Gaebler 1992; Hood 1991, 1995) and to enhance the government performance, the New Public Management (NPM) approach was introduced to public sector organisations (Diefenbach 2009). Generally, NPM reflects global reorganisation of public sector organisations (Buick et al. 2015) by making them much more "business-like" (Diefenbach 2009). The core idea of NPM was a stronger performance orientation, with emphasis on higher labour productivity, establishing standards and measures of performance, and a focus on outcomes rather than inputs (Osborne and Gaebler 1992; Hood 1991; Lynn 1998). As a result, more attention has been devoted to employee performance management. Relying on the prior studies (Buchner 2007; Pulakos 2009; Aguinis 2014), debates in the field of public sector employee performance management mainly focus on two areas: the ways to best manage employee performance (West and Blackman 2015) and the benefits for the organisations and employees from well-designed and established performance man- 
agement (Aguinis and Pierce 2008; Aguinis et al. 2011). This paper belongs to the last stream of research addressing some of these benefits such as the outcomes of performance management. By focusing on goal setting and feedback as the components of leaders' behaviour in performance management, the paper emphasises the role played by line managers as leaders (Schwarz et al. 2020), and argues that performance management is a much broader concept in comparison to performance appraisal (Aguinis 2014).

Although the ultimate objective of performance management implies increased performance, the researchers argue that performance can be considered as a distal outcome of the process (Gruman and Saks 2011). Consequently, previous studies have analysed more proximal outcomes of performance management, in terms of cognitive, affective and conative outcomes, such as affective commitment (Norris-Watts and Levy 2004) and turnover intention (Van Waeyenberg et al. 2017). More recently, work engagement has started to attract attention, referring to it as to the positive result of performance management; however, still there is a dearth of studies that focus on performance management as the antecedent of work engagement in public organisations (West and Blackman 2015; Andrews and Mostafa 2019; Awan et al. 2020). Furthermore, this happens despite the relevance of the concept of work engagement (Ancarani et al. 2018), as disengaged employees are costly to public organisations due to their potential to negatively influence public service delivery (Andrews and Mostafa 2019). Moreover, engaged employees approach the tasks associated with their job with a sense of self-investment, passion, and energy, and this might translate into higher levels of their in-role and extra-role performance (Christian et al. 2011), which in turn has the potential to enhance the government performance as a whole. In general, the prevailing conclusion in the literature claims that very limited attention has been given by public administration scholars to antecedents of work engagement in public service organisations (Mostafa and El-Motalib 2020). Along these lines, the paper addresses the mentioned gap while dealing with leaders' behaviour in performance management as the determinant of work engagement in the public sector.

Going further, previous studies in management field argue that the relationship between the two constructs might not be of direct nature only (Jiang et al. 2012; Alfes et al. 2013; Zhang et al. 2020). The general call encourages the researchers to explain the mechanism through which one construct impacts another (Paauwe 2009), analysing the potential for mediating or moderating processes. This paper responds to the mentioned call presuming that organisational justice plays a mediating role in the relationship between leaders' behaviour in performance management and work engagement in the public sector. The argumentation of such a claim lies in several aspects. First, as employees increasingly tend to judge the decisions made by organisations by asking the question "Was that fair?" (Colquitt et al. 2001), the relevance of organisational justice per se increases. Next, because of the potential of organisational justice to explain a wide range of employee behaviours (Greenberg 1990), higher or lower work engagement level might be justified. Further, there is some empirical evidence in the public sector (albeit scant) demonstrating that the rising organisational justice perception increases employee work engagement (Özer et al. 2017). Finally, to the best knowledge of the authors of this paper, there is no paper analysing the mediating effect of organisational justice in the relationship between leaders' behaviour in performance management and work engagement in the public sector.

The aim of this paper is to reveal the linkage between leaders' behaviour in performance management, work engagement, and organisational justice in the public sector. In doing this, the paper seeks to answer the following: (a) What do we mean by leaders' behaviour in performance management? How is performance management described in terms of goal setting and feedback provision to employees? (b) How can work engagement and organisational justice be characterised? (c) Will goal setting and feedback provision to employees result in a positive effect on work engagement in the public sector? (d) Will leaders' behaviour in performance management impact the organisational justice? Will organisational justice make an impact on the work engagement? (e) What is the role of 
organisational justice exploring the linkage between leaders' behaviour in performance management and work engagement?

In order to answer these questions, this paper analyses data from the survey carried out in the public sector in Lithuania. The questionnaires were distributed online while the sample consisted of public sector employees employed by state or municipal public sector organisations. For testing the hypotheses, multiple regression analyses were conducted.

The paper contributes to the literature in several ways. Firstly, the contemporary literature on performance management is calling to revise the performance management by broadening its meaning and incorporating in it not only performance appraisal, but also performance agreement, performance facilitation, and feedback (Armstrong 2018). The paper contributes to such a call by focusing on leaders' behaviour in performance management in terms of goal setting and feedback for employees. Secondly, some researchers (Rubin 2009) argue that, "little scholarly effort has been invested in exploring the relationships between organisational justice and the outcomes in public sector settings" (Choi 2011, p. 186). The current paper seeks to narrow this gap by exploring whether and how organisational justice impacts work engagement in the public sector. Thirdly, the search and analysis of the direct linkage between the two constructs do not allow for presenting the holistic model. For such a model, a mechanism is needed to explain the way the impact occurs. The current paper is designed to explore the mechanism by which leaders' behaviour in performance management influences the work engagement. The mediating role of organisational justice is analysed. Fourth, two theories, namely social exchange theory (SET) (Blau 1964) and conservation of resources theory (COR) (Hobfoll 1989) are used for explaining the relationship between leaders' behaviour in performance management and organisational justice and work engagement. Both theories are well suited for explaining the mentioned relationship. SET suggests that social behaviour is the result of an exchange process, where two aspects (cost and benefit) are involved. Accordingly, each employee compares benefits and costs and bases the action decision on the expectation that it will maximise profit (Zhao and Detlor 2021). Meanwhile, COR theory describes the motivation that drives the employees to both maintain their current resources and to pursue new ones (Hobfoll 1989).

The remainder of the paper is structured as follows. Theoretical part gives an overview of the literature on performance management in the public sector and describes work engagement and organisational justice. Later, the hypotheses are developed. Then, the research method applied is described. The empirical results and discussion come further. Finally, conclusions are drawn.

\section{Theoretical Background}

\subsection{Leaders Behaviour in Performance Management in the Public Sector}

Although literature provides several definitions of performance management (for review see Armstrong 2018), the essence of the construct is well revealed by the suggestion that "performance management is the continuous process of improving performance by setting individual and team goals which are aligned to the strategic goals of the organisation, planning performance to achieve the goals, reviewing and assessing progress, and developing the knowledge, skills and abilities of people" (Armstrong 2018, p. 7). Moreover, it is assumed that managers in the public sector should behave mainly as transformational leaders, exercising moderate transactional relationships with their employees, thus, ensuring integrity and ethics in the performance of their tasks (Orazi et al. 2013).

Apparently, two characteristics serve as keystones for better understanding what performance management is about, namely, an ongoing process and alignment with strategic goals (Aguinis 2014). Ongoing process implies a never-ending process of setting goals, observing performance, and giving and receiving coaching and feedback (Aguinis 2014). Due to ongoing nature, performance management is far broader than just performance appraisal (Teeroovengadum et al. 2019; Claus and Briscoe 2009). The second characteristic highlights the link between employee performance and organisational goals and thereby all 
employees are not only encouraged to contribute to strategic direction of the organisation, but also are allowed to see that contribution explicitly (Aguinis 2014; Becker et al. 2011).

Thus, performance management aims at identifying, measuring, and developing the employee performance through a cycle comprising several stages (Aguinis and Pierce 2008). The literature review allows concluding that there are numerous models of performance management; however, generally, they consist of a sequence of stages or activities such as performance agreement/goal setting, performance monitoring/facilitation, performance appraisal and feedback, and improved performance (Armstrong 2018). As the scope of performance management is broad, the paper limits its focus further on two components only: leaders' behaviour in performance agreement by goal setting, and performance feedback. From previous literature it seems that organisations in general, and especially in the public sector, mostly struggle with the mentioned aspects of performance management (Van der Hoek et al. 2018), as less than a third of employees believe that their organisation's performance management process assists them in improving their performance (Pulakos 2009). The next paragraphs briefly explore each of these components.

Generally, leaders' behaviour performance agreement involves the negotiation of goals that employees will attain. Thus, employees' goals are set during performance planning (Van Waeyenberg et al. 2017). A goal can be defined as the object or aim of an action, usually within a specified time limit (Locke and Latham 2002). More specifically, goal is the object or aim of an action that, therefore, serves as the standard against which one compares his or her performance (Locke and Latham 1990; Locke and Latham 2020). In other words, goals define the desired outcomes or performance that should be realised (Van der Hoek et al. 2018).

In the 1990s, Locke and Latham developed a goal-setting theory, explaining an individual's performance by looking at the goals that are set. The concept of a goal is predicated on observing the actions of living organisms (Locke and Latham 2020). The goal-setting theory is based on the notion that conscious human behaviour is purposeful (Latham and Locke 1991). Thus, goal setting can be used as a motivational technique (Yearta et al. 1995).

According to the goal-setting theory, goals affect performance through four causal mechanisms (Locke and Latham 2002). First, goals serve a directive function. They direct an employee's attention and effort towards goal-relevant activities, leaving goal-irrelevant activities offside. Second, goals have an energising function. Thus, high goals lead to greater effort than low goals. Third, goals also affect persistence. As such, when participants are allowed to control the time they spend on a task, hard goals prolong the effort. Fourth, goals affect action indirectly by leading to the discovery, arousal, and use of task-relevant knowledge and strategies (Locke and Latham 2002).

The effective use of goal-setting theory was supported by the identification of goal setting components by Lee et al. (1991). Lee et al. (1991) proposed 10 goal setting components, namely supervisor support/participation; goal stress; goal efficacy; goal rationale; use of goal setting in performance appraisal; tangible rewards; goal conflict; organisational facilitation of goal achievement; dysfunctional effects of goals; and goal clarity.

The empirical part of the paper focuses on several components of goal setting, namely goal rationale, goal clarity, organisational facilitation of goal achievement, and use of goal setting in performance appraisal. The mentioned components are highly relevant seeing that due to political or other reasons even organisational goals might sound quite complicated and unclear (Blackman et al. 2012; Diefenbach 2009). In such situations, leaders in the public sector nonetheless remain responsible for the quality of goals setting.

Goal clarity refers to clear expression (formulation) of goals and clear prioritisation of the agreed goals. Goal rationale expresses the logic of the goals, as the employee should understand clearly why some goals are set for them, to perceive how performance is being measured and obtain regular feedback on performance quality. Organisational facilitation of goal achievement may involve the provision of additional equipment, time, money, or people for proper goal execution. Goal setting in performance appraisal can be used to increase both goal acceptance and motivation of employees (Lee et al. 1991). 
Feedback is yet another essential component of leaders' behaviour in performance management. Ilgen et al. (1979) treat feedback as a special case of the general communications process in which a sender conveys a message to the recipient; the message typically contains information about the recipient. Turning to performance feedback, mainly there are two sources, supervisors and co-workers. As the majority of research has focused on the supervisor feedback, given that supervisors have more formal authority over work outcomes (Dahling et al. 2017), this paper does the same.

According to Armstrong (2018), feedback is "a provision of information to people on how they have performed in terms of results, events, critical incidents and significant behaviours" (p. 117). Feedback usually contains informal behavioural expectations that managers desire from their subordinates and unambiguous performance evaluations of the subordinates (Kluger and DeNisi 1996). Feedback can be positive, constructive, and negative (Armstrong 2018). Positive feedback occurs when employees are informed about how well they have performed. Feedback is constructive when it provides employees with advice on how to do better, how they can improve their behaviours and results. Negative feedback is that which tells employees that they have performed badly (Armstrong 2018). In general, feedback does not aim at changing employees into what their managers would like them to be, but rather aims at providing them with information about their behaviours and performance (Diefenbach 2009; Banfield and Kay 2012). Several aspects of feedback messages have been proposed in previous studies (Steelman et al. 2004; Rosen et al. 2006; Guo and Ling 2020), including feedback quality, feedback availability, source credibility, and feedback delivery. These aspects are the analysis object of the current paper and are briefly explained below.

Source credibility is conceptualised as the feedback source's expertise and trustworthiness. Source expertise covers knowledge of the feedback recipient's job requirements, knowledge of the employee's actual job performance, and the ability to judge that job performance accurately. Trustworthiness addresses the fact whether an employee trusts the feedback source to provide accurate performance information (Steelman et al. 2004). Feedback quality is an important part of the interpersonal communication between leaders and followers (Guo and Ling 2020). Feedback quality refers to consistency and usefulness of the message (Steelman et al. 2004). Moreover, feedback quality can determine the willingness of an employee to respond to the feedback (Ilgen et al. 1979). As regards the feedback delivery, the feedback recipient's perceptions of the source's intentions in giving feedback will affect the reactions and responses to the feedback (Steelman et al. 2004). The general rule is that the more considerate the feedback source is when providing feedback, the more likely an individual is to accept and respond to such feedback (Steelman et al. 2004). Speaking of the source availability, it captures the extent to which feedback sources are accessible (Young and Steelman 2014). There is a need to get the information available in informal day-to-day communications at work seeking to meet the goals (Steelman et al. 2004). Thus, in general, all the mentioned feedback aspects are highly relevant addressing feedback, especially in the public sector where quite often it is formal, not constructive, and does not identify the ways to improve the performance for the employee (Blackman et al. 2012).

Summing up, although the focus on leaders' behaviour in performance management is not new, the content, relevance, and added value of performance management, especially in the public sector, still need investigation, especially linking them to employee attitudes and behaviour.

\subsection{Work Engagement}

According to the Gallup survey, $85 \%$ of employees worldwide are not engaged or are actively disengaged in their job (Mann and Harter 2016; Gallup 2017). Throughout Western Europe, employee engagement level is just $10 \%$ of the employed population, while in Eastern Europe only 15\% of the employed population feel engaged (involved in and enthusiastic about their work) (Gallup 2017). Moving to the public sector, the results 
demonstrate that US federal government workers were less engaged and more disengaged than their counterparts in the US private sector (Ander and Swift 2014). Given this focus, the enhancement of work engagement is an issue, challenge, and ambition.

This paper follows the work engagement definition provided by Schaufeli et al. (2002), which defines work engagement "as a positive, fulfilling, work-related state of mind that is characterised by vigour, dedication, and absorption" (p. 74). In this context, engagement refers to a more persistent and pervasive affective cognitive state that is not focused on any particular object, event, individual, or behaviour. Thus, engagement is conceptualised as a three-dimensional construct. Vigour is defined by high levels of energy and mental resilience while working, willingness to invest effort in one's work, and persistence even when faced with difficulties. Dedication is characterised by the sense of enthusiasm, inspiration, pride, significance, and challenge. Absorption refers to being fully concentrated and deeply engrossed in one's work, where time passes quickly and one has difficulties with detaching oneself from work (Schaufeli et al. 2002). This paper follows the work engagement definition provided by Schaufeli et al. (2002).

\subsection{Organisational Justice}

In recent years, organisational justice has gained increasing attention as it can explain a wide range of employee behaviour (Greenberg 1990; Mylona and Mihail 2019; Tahir Farid et al. 2019). Organisational justice is a personal evaluation about the ethical and moral standing of managerial conduct (Cropanzano et al. 2007). Organisational justice refers to the perception of justice that an organisation's participants rate to decide whether the organisation is fair from their perspective or point of view (Cugueró-Escofet et al. 2019). The distribution of resources, decision-making processes, or interpersonal behaviours are only a few of the workplace concerns relevant to organisational justice (Özer et al. 2017). Organisational justice refers to several forms of perceived justice, and each of these provides an answer to the question "what is fair" (Greenberg 1990).

Usually, organisational justice is conceptualised as a four-dimensional construct, namely distributive, procedural, interpersonal, and informational justice. Distributive justice refers to the fairness of outcomes for individuals in comparison with what the individual perceives to be a fair evaluation (Farndale et al. 2011). Colquitt et al. (2001) state that distributive justice exists to the extent that the allocation of an outcome is consistent with the goals of a particular situation. Procedural justice refers to the individual's perception of the fairness of the process carried out (Farndale et al. 2011). Interpersonal justice refers to the degree to which people are treated with dignity, politeness, and respect by third parties when decision processes and decisions themselves are implemented. Finally, informational justice refers to the extent to which the employees feel they have adequate information about why procedures were used in a certain way or why outcomes were distributed in a certain manner (Colquitt et al. 2001).

\subsection{Linking Leaders' Behaviour in Performance Management, Work Engagement, and Organisational Justice: Hypothesis Development}

The development of hypotheses is based on SET (Blau 1964) and COR theory (Hobfoll 1989). SET is among the most influential conceptual paradigms for understanding workplace attitudes and behaviour (Blau 1964; Cropanzano and Mitchell 2005; Cook et al. 2013), while COR theory (Hobfoll 1989) may clarify the dynamic relationship between various types of resources (i.e., feedback) and work attitudes (i.e., engagement).

Blau (1964) viewed social exchange as a process of central significance in social life and as underlying the relations between groups as well as between individuals. Within the aim of this paper, the relationship between employee and line manager while implementing performance management are of interest. According to Blau (1964), "Social exchange $<$. . > refers to voluntary actions of individuals that are motivated by the returns they are expected to bring and typically do in fact bring from others." (p. 91). One of the basic ideas of social exchange theory is that relationships evolve over time into trusting, loyal, and mutual commitments (Cropanzano and Mitchell 2005). To do so, stakeholders must 
observe certain "rules" of exchange and reciprocity is probably the best-known exchange rule (Cropanzano and Mitchell 2005).

COR theory proposes a model of individual motivation because the acquisition and accumulation of resources are considered to be a pivotal drive that initiates and maintains people's behaviour (Salanova et al. 2010).

As it was mentioned previously, the current paper limits its focus on two components of leaders behaviour in performance management, namely goal setting and feedback. Due to this, the hypotheses are further developed having these components in mind.

\subsubsection{Leaders' Behaviour in Performance Management and Employee Engagement}

Consistent with the SET, it could be claimed that work engagement may be interpreted as the individual response to the exchange for goal clarity, rationality, and facilitation while achieving and using goals for appraisal (Cropanzano and Mitchell 2005). When goals are ambiguous and unclear, difficult to achieve or the reasons behind them are not clear, employees must work harder to understand the relationship between the activities they undertake and the resulting performance (Andrews and Mostafa 2019). Under such circumstances employees are more likely to show lower engagement because they are not certain whether investment in certain activities will be time and effort well spent (Andrews and Mostafa 2019; Jung 2014).

Turning to empirical evidence, their number is quite limited. For instance, Andrews and Mostafa (Andrews and Mostafa 2019) found a negative relationship between goal ambiguity and work engagement for senior public managers.

Concerning feedback and work engagement linkage, Salanova et al. (2010) apply the COR theory and argue that people try to acquire resources at work that they value, such as feedback about their performance and, accordingly, feedback as a job resource initiates a motivational process that may lead to work engagement. In a longitudinal study, Xanthopoulou et al. (2009) found that job resources, including feedback, were positively associated with engagement approximately 18 months later. Gruman and Saks (2011) conclude that positive feedback is likely to promote engagement.

In the light of the mentioned explanations, it is suggested that:

Hypothesis 1 (H1). Goal setting will be positively related to employee engagement.

Hypothesis 1a (H1a). Goal rationale will be positively related to employee engagement.

Hypothesis $\mathbf{1 b}$ (H1b). Goal clarity will be positively related to employee engagement.

Hypothesis 1c (H1c). Organisational facilitation of goal achievement will be positively related to employee engagement.

Hypothesis 1d (H1d). Use of goal setting in performance appraisal will be positively related to employee engagement.

Hypothesis 2 (H2). Feedback will be positively related to employee engagement.

Hypothesis 2a (H2a). Source credibility will be positively related to employee engagement.

Hypothesis $\mathbf{2 b} \mathbf{b} \mathbf{H} \mathbf{2} \mathbf{b})$. Feedback quality will be positively related to employee engagement.

Hypothesis 2c (H2c). Feedback delivery will be positively related to employee engagement.

Hypothesis 2d (H2d). Source availability will be positively related to employee engagement. 
2.4.2. Leaders' Behaviour in Performance Management and Organisational Justice

Latham et al. (2005) argue that employee perception of fairness is the key element in relation to effective performance management. As such, leaders' behaviour in performance management could act as a driver enhancing the organisational justice. For instance, Cropanzano et al. (Cropanzano et al. 2007) argue that the components of performance management, in terms of reward systems and performance appraisal, can promote the organisational justice. Elicker et al. (2019) argue that when looking at feedback, more specifically at source credibility, it is important to consider perceptions of fairness. Therefore, the paper hypothesises the following, concerning the linkage between performance management and organisational justice:

Hypothesis 3 (H3). Goal setting will be positively related to organisational justice.

Hypothesis 3a (H3a). Goal rationale will be positively related to organisational justice.

Hypothesis $3 \mathbf{b} \mathbf{( H 3 b ) . ~ G o a l ~ c l a r i t y ~ w i l l ~ b e ~ p o s i t i v e l y ~ r e l a t e d ~ t o ~ o r g a n i s a t i o n a l ~ j u s t i c e . ~}$

Hypothesis 3c (H3c). Organisational facilitation of goal achievement will be positively related to organisational justice.

Hypothesis $\mathbf{3 d}$ (H3d). Use of goal setting in performance appraisal will be positively related to organisational justice

Hypothesis 4 (H4). Feedback will be positively related to organisational justice.

Hypothesis 4a (H4a). Source credibility will be positively related to organisational justice.

Hypothesis $\mathbf{4 b} \mathbf{( H 4 b ) . ~ F e e d b a c k ~ q u a l i t y ~ w i l l ~ b e ~ p o s i t i v e l y ~ r e l a t e d ~ t o ~ o r g a n i s a t i o n a l ~ j u s t i c e . ~}$

Hypothesis 4c (H4c). Feedback delivery will be positively related to organisational justice.

Hypothesis $\mathbf{4 d} \mathbf{( H 4 d )}$. Source availability will be positively related to organisational justice.

\subsubsection{Organisational Justice and Employee Engagement}

Drawing upon SET, previous research has indicated that organisational justice would be directly associated with the quality of social exchange between various stakeholders and in turn might lead to engagement (Kashyap et al. 2007; Biswas et al. 2013; Ghosh et al. 2014). Further, organisational justice perceptions may be looked upon as resources (COR theory), which may be instrumental in increasing work engagement because of their functional role in goal accomplishment (Ghosh et al. 2014).

The previous findings strongly support the relationship between the organisational justice and engagement. Maslach and Leiter (2008) have demonstrated that fairness is associated with engagement. Similarly, Saks (2006) revealed that procedural and distributive justice were positively related to organisational engagement and job engagement. Additionally, Moliner et al. (2008) found positive correlations between the three components of justice and engagement. Ghosh et al. (2014) while exploring public sector banks in India found that distributive, procedural, and interactional justice were related to work engagement. More recently, Özer et al. (2017) found that rising organisational justice perception statistically increases employees' work engagement in the health care sector. Thus, given the foregoing, it is suggested that:

Hypothesis 5 (H5). Organisational justice will be positively related to employee engagement.

Hypothesis 5a (H5a). Distributive justice will be positively related to employee engagement. 
Hypothesis $\mathbf{5 b} \mathbf{b} \mathbf{H} \mathbf{b})$. Procedural justice will be positively related to employee engagement

Hypothesis 5c (H5c). Interpersonal justice will be positively related to employee engagement

Hypothesis 5d (H5d). Informational justice will be positively related to employee engagement.

2.4.4. Organisational Justice as a Mediator in the Linkage of Leaders' Behaviour in Performance Management and Employee Engagement

Previous studies support the notion that organisational justice has a mediating role explaining a wide range of employee behaviour. For instance, Farndale et al. (2011) found that employee experiences of high commitment performance management practices and their level of commitment were strongly mediated by perceptions of organisational justice. This paper anticipates that such a mediating role could be possible in the performance management field, addressing the linkage between goal setting and engagement; and feedback and engagement.

The employees perceive the extent to which goals are set and feedback is provided as being fair or not and equitable or not (Maslach and Leiter 2008), and such perceptions of fairness could create a mediating effect of justice between performance management and engagement. Thus, the hypotheses are as follows:

Hypothesis 6 (H6). Organisational justice will mediate the relationship between goal setting and employee engagement.

Hypothesis 7 (H7). Organisational justice will mediate the relationship between feedback and employee engagement.

Following the mentioned hypotheses, a theoretical research model is provided in Figure 1.

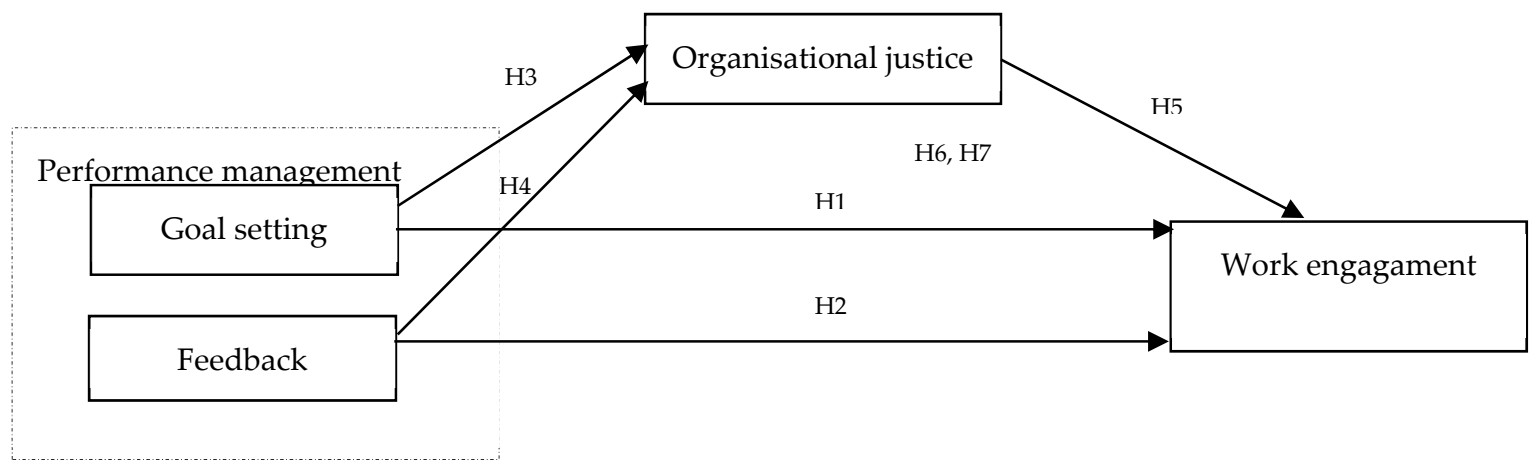

Figure 1. Theoretical research model.

\section{Methodology}

\subsection{Sample and Data Collection}

The quantitative study was conducted in Lithuania, which is a special country, since it survived a long period of occupation, thirty years ago restored its independence and fifteen years ago joined the European Union (EU) (Liobikienè et al. 2020). After the restoration of independence in 1990, the institutional system that made up the public sector was not recreated and it remained "inherited" as a product created by the socialist planned economy (Lietuvos Respublikos Vidaus Reikalu Ministerija 2020). As such, a multitude of different reforms was proposed by Lithuanian authorities or the European Commission in order to increase its efficiency and for it to correspond to the needs of the citizens. It is noteworthy that the reforms mainly focused on the areas of organisation and management of government, service delivery, and digitalisation as well as civil service and 
human resource management (Nakrošis 2018b). Although over the last four years, people's trust in the public sector institutions has grown (Lietuvos Respublikos Vidaus Reikalu Ministerija 2020), the most important barrier of public sector innovation in Lithuania is the lack of sufficient human or financial resources (Raipa and Giedraityte 2014). Incidentally, according to the International Civil Service Effectiveness Index, Lithuania is the 20th among 38 countries and two places below the average. Among the EU countries, Lithuania holds the 11th position (Lietuvos Respublikos Vidaus Reikalu Ministerija 2020).

Lithuania is a unitary state with two levels of government-central government and local governments (Nakrošis 2018a, 2018b). In 2018, a total of 4120 organisations operated in the public sector, of which 751 or less than one fifth, belonged to the state public sector, and the municipal public sector owned 3369 or more than $80 \%$ of organisations (Viešojo Sektoriaus Pokyčiai: Mažeja Darbuotojų ir Organizacijų, o Atlyginimai Auga 2019). In 2018, the average number of employees in the public sector was 354,000 or $25 \%$ of all Lithuanian employees (Lietuvos Respublikos Vidaus Reikalu Ministerija 2020).

As it was mentioned in the Introduction, in order to gather the data and to test the hypotheses, the target group of this research consisted of employees working in the public sector in Lithuania. Data were collected using a convenience sampling. Convenience sampling is a type of nonprobability sampling where members of the target population that meet certain practical criteria, such as easy accessibility, availability at a given time, geographical proximity, or the willingness to participate are included for the purpose of the study (Etikan et al. 2016). Forty-five central and local public sector organisations were chosen randomly. Calls were made and emails were sent to human resource managers of these organisations asking them to contribute to the research and distribute the electronic questionnaires to employees of their organisations. While distributing the questionnaires, information about the purpose of the survey and a link to a survey were sent. The cover page of the questionnaire contained the information about the anonymity and voluntary nature of the research. Due to the way of disseminating the questionnaire, it was impossible to estimate the number of persons the questionnaires were sent to and the response rate. Data collection took more than two months. Finally, 299 questionnaires were collected. According to the numbers of the employees working in the public sector in Lithuania $(354,000)$, this number of responses reflected an acceptable bias of $5.8 \%$, which indicated the reliability of the data.

The socio-demographic characteristics of the sample are reported in Table 1.

Table 1. Respondents' profile.

\begin{tabular}{ccc}
\hline & Number & Percentage (\%) \\
\hline Gender & 64 & 21.4 \\
Male & 235 & 78.6 \\
Female & & 3.3 \\
Age & 10 & 13.7 \\
Till 24 years old & 41 & 28.1 \\
35-34 years old & 84 & 29.2 \\
35-44 years old & 87 & 21.7 \\
45-54 years old & 65 & 4.0 \\
55-pre-retirement age & 12 & 18.73 \\
Working retirees & & 81.27 \\
\hline Position & 56 & 243 \\
\hline
\end{tabular}

As it is seen from Table 1, 235 of respondents were women. Only 56 respondents held a managerial position. 


\subsection{Measures}

Data were collected using questionnaires in Lithuanian, which were first drafted in English. Once the English questionnaire was ready, the items were translated into Lithuanian and then back into English for verification, i.e., to make sure the original and translated English items matched.

Goal setting was measured using the scale of Lee et al. (1991), which employs four dimensions of goal setting, namely: goal rationale (4 items), goal clarity (5 items), organisational facilitation of goal achievement ( 5 items), and use of goal setting in performance appraisal (9 items). Feedback was measured using the scale of Steelman et al. (2004), taking four dimensions, namely source credibility (5 items), feedback quality (5 items), feedback delivery ( 5 items), and source availability ( 5 items) into account. Work engagement was measured using a widely used 17-item version of Utrecht's Work Engagement Scale (Schaufeli et al. 2006). Organisational justice was measured using the Colquitt's (Colquitt et al. 2001) organisational justice scale, which includes 20 items. All items are provided in Appendix A. The respondents rated items for all of these measures on a 5-point Likert-type scale (1-“strongly disagree", 5-“"strongly agree").

\subsection{Data Analysis}

Statistical analysis was performed using the statistical package IBM SPSS Statistics Standard v.23. All measures were subjected to reliability analysis. In case of goal setting, Cronbach's alpha values were calculated as follows: $\alpha=0.846$ for goal rationale; $\alpha=0.697$ for goal clarity; $\alpha=0.747$ for organisational facilitation of goal achievement; and $\alpha=0.900$ for use of goal setting in performance appraisal. Regarding feedback, Cronbach's alpha was $\alpha=0.519$ for source credibility; $\alpha=0.588$ for feedback quality; $\alpha=0.721$ for feedback delivery; and $\alpha=0.675$ for source availability. Cronbach's alpha for work engagement was $\alpha=0.907$. Turning to organisational justice, Cronbach's alpha was $\alpha=0.805$ for distributive justice; $\alpha=0.928$ for procedural justice; $\alpha=0.897$ for interpersonal justice; and $\alpha=0.911$ for informational justice. As all Cronbach's alpha coefficients exceeded 0.7, all measures were considered acceptable for the analysis (Nunnally 1978).

Respondents' demographics were summarised using descriptive statistics. As the data had a skewed distribution, the Spearman's coefficient was used as a measure of bivariate correlations between the main variables of the study. Multiple regression analyses were conducted to examine the relationships between constructs. Results were considered statistically significant at a $5 \%(p<0.05)$ significance level.

\section{Results and Discussion}

The means, standard deviations for the scales and correlation matrix are provided in Table 2.

As it is seen from Table 2, the mean of ratings of goal setting is 3.61, meanwhile, feedback (mean 3.52) has been rated slightly lower. According to the respondents, they are highly engaged in work (mean $=3.69$ ). Finally, organisational justice has been evaluated as sufficiently highly expressed (mean $=3.56$ ).

Referring to Table 2, a positive correlation between goal setting and work engagement $(0.508$, $p<0.01)$ and organisation justice $(0.804, p<0.01)$ has been revealed. The same situation has been observed with respect to feedback, seeing that there are positive correlations between work engagement $(0.411, p<0.01)$ and organisation justice $(0.706, p<0.01)$.

To test the study hypotheses, multiple regression analyses were conducted (Table 3 ). The results are discussed further. 
Table 2. Means, standard deviations, and correlations.

\begin{tabular}{|c|c|c|c|c|c|c|c|c|c|c|c|c|c|c|c|c|c|c|}
\hline Constructs & Mean & SD & 1 & 2 & 3 & 4 & 5 & 6 & 7 & 8 & 9 & 10 & 11 & 12 & 13 & 14 & 15 & 16 \\
\hline 1. Goal rationale & 3.5978 & 0.76155 & & & & & & & & & & & & & & & & \\
\hline 2. Goal clarity & 3.8353 & 0.59838 & $0.387^{* *}$ & & & & & & & & & & & & & & & \\
\hline $\begin{array}{l}\text { 3. Organisational } \\
\text { facilitation of goal } \\
\text { achievement }\end{array}$ & 3.5880 & 0.63085 & $0.573^{* *}$ & $0.495^{* *}$ & & & & & & & & & & & & & & \\
\hline $\begin{array}{l}\text { 4. Use of goal } \\
\text { setting in } \\
\text { performance } \\
\text { appraisal }\end{array}$ & 3.5392 & 0.67750 & $0.646^{* *}$ & $0.415^{* *}$ & $0.633^{* *}$ & & & & & & & & & & & & & \\
\hline 5. Goal setting & 3.6148 & 0.55058 & 0.802 ** & 0.633 ** & $0.821 * *$ & $0.913^{* *}$ & & & & & & & & & & & & \\
\hline $\begin{array}{l}\text { 6. Distributive } \\
\text { justice }\end{array}$ & 3.4950 & 0.76795 & $0.559 * *$ & $0.387^{* *}$ & $0.588^{* *}$ & $0.536^{* *}$ & 0.640 ** & & & & & & & & & & & \\
\hline $\begin{array}{l}\text { 7. Procedural } \\
\text { justice }\end{array}$ & 3.2179 & 0.57896 & 0.472 ** & $0.363^{* *}$ & $0.637^{* *}$ & $0.648^{* *}$ & $0.683^{* *}$ & $0.656^{* *}$ & & & & & & & & & & \\
\hline $\begin{array}{l}\text { 8. Interpersonal } \\
\text { justice }\end{array}$ & 4.0443 & 0.64921 & $0.449^{* *}$ & 0.369 ** & $0.498^{* *}$ & $0.547^{* *}$ & 0.591 ** & $0.443 * *$ & $0.424^{* *}$ & & & & & & & & & \\
\hline $\begin{array}{l}\text { 9. Informational } \\
\text { justice }\end{array}$ & 3.7344 & 0.73108 & 0.531 ** & 0.401 ** & $0.532 * *$ & $0.649^{* *}$ & $0.678^{* *}$ & $0.489^{* *}$ & 0.503 ** & 0.750 ** & & & & & & & & \\
\hline $\begin{array}{l}\text { 10. Organisational } \\
\text { justice }\end{array}$ & 3.5677 & 0.54411 & $0.619^{* *}$ & $0.467^{* *}$ & $0.701 * *$ & 0.741 ** & 0.804 ** & $0.797^{* *}$ & $0.828 * *$ & $0.774^{* *}$ & $0.840^{* *}$ & & & & & & & \\
\hline $\begin{array}{l}\text { 11. Source } \\
\text { credibility }\end{array}$ & 3.4890 & 0.52989 & $0.553^{* *}$ & $0.355^{* *}$ & $0.546^{* *}$ & $0.599 * *$ & 0.653 ** & $0.550^{* *}$ & 0.541 ** & $0.574^{* *}$ & $0.660^{* *}$ & $0.716^{* *}$ & & & & & & \\
\hline $\begin{array}{l}\text { 12. Feedback } \\
\text { quality }\end{array}$ & 3.6288 & 0.47442 & 0.528 ** & 0.298 ** & $0.528^{* *}$ & $0.630^{* *}$ & $0.646^{* *}$ & $0.481 * *$ & $0.509 * *$ & $0.527^{* *}$ & $0.610^{* *}$ & $0.656^{* *}$ & $0.713^{* *}$ & & & & & \\
\hline $\begin{array}{l}\text { 13. Feedback } \\
\text { delivery }\end{array}$ & 3.5318 & 0.63766 & $0.423 * *$ & $0.251 * *$ & $0.393 * *$ & $0.527^{* *}$ & $0.524 * *$ & $0.397^{* *}$ & $0.374^{* *}$ & $0.530 * *$ & $0.544^{* *}$ & $0.560^{* *}$ & $0.536^{* *}$ & $0.484^{* *}$ & & & & \\
\hline $\begin{array}{l}\text { 14. Source } \\
\text { availability }\end{array}$ & 3.4609 & 0.61210 & 0.373 ** & $0.222 * *$ & $0.336^{* *}$ & $0.334^{* *}$ & 0.393 ** & $0.303 * *$ & $0.263^{* *}$ & $0.339^{* *}$ & $0.319^{* *}$ & $0.372 * *$ & $0.356^{* *}$ & 0.359 ** & $0.631^{* *}$ & & & \\
\hline 15. Feedback & 3.5276 & 0.44871 & 0.579 ** & $0.346^{* *}$ & $0.554^{* *}$ & 0.643 ** & 0.682 ** & 0.530 ** & $0.515^{* *}$ & $0.609 * *$ & 0.653 ** & $0.706^{* *}$ & $0.784^{* *}$ & $0.776^{* *}$ & 0.850 ** & $0.770 * *$ & & \\
\hline $\begin{array}{l}\text { 16. Work } \\
\text { engagement }\end{array}$ & 3.6953 & 0.49263 & $0.404^{* *}$ & 0.403 ** & $0.481^{* *}$ & $0.400^{* *}$ & $0.508^{* *}$ & $0.378^{* *}$ & $0.315^{* *}$ & $0.457^{* *}$ & $0.452 * *$ & $0.485^{* *}$ & $0.388^{* *}$ & 0.370 ** & $0.295^{* *}$ & $0.276^{* *}$ & 0.411 & \\
\hline
\end{tabular}


Table 3. Regression analysis.

\begin{tabular}{|c|c|c|c|c|c|c|c|c|c|c|}
\hline 1 & 2 & 3 & 4 & 5 & 6 & 7 & 8 & 9 & 10 & 11 \\
\hline & $\begin{array}{l}\text { Engagement } \\
\text { H1a-H1d }\end{array}$ & Engagement H1 & $\begin{array}{l}\text { Engagement } \\
\text { H2a-H2d }\end{array}$ & Engagement $\mathrm{H} 2$ & $\begin{array}{c}\text { Organisational } \\
\text { Justice } \\
\text { H3a-H3d }\end{array}$ & $\begin{array}{c}\text { Organisational } \\
\text { Justice } \\
\text { H3 }\end{array}$ & $\begin{array}{c}\text { Organisational } \\
\text { Justice } \\
\text { H4a-H4d }\end{array}$ & $\begin{array}{c}\text { Organisational } \\
\text { Justice } \\
\text { H4 }\end{array}$ & $\begin{array}{c}\text { Engagement } \\
\text { H5a-H5d }\end{array}$ & $\begin{array}{c}\text { Engagement } \\
\text { H5 }\end{array}$ \\
\hline Goal rationale & $0.136^{*}$ & & & & $0.134^{* *}$ & & & & & \\
\hline Goal clarity & 0.191 ** & & & & $0.085^{*}$ & & & & & \\
\hline $\begin{array}{l}\text { Organisational } \\
\text { facilitation of goal } \\
\text { achievement }\end{array}$ & $0.269 * * *$ & & & & $0.317^{* * *}$ & & & & & \\
\hline $\begin{array}{l}\text { Use of goal setting in } \\
\text { performance appraisal }\end{array}$ & 0.062 & & & & $0.419^{* * *}$ & & & & & \\
\hline Goal setting & & $0.508^{* * *}$ & & & & $0.804^{* * *}$ & & & & \\
\hline Source credibility & & & $0.220^{* *}$ & & & & $0.422^{* * *}$ & & & \\
\hline Feedback quality & & & $0.157^{*}$ & & & & $0.253^{* * *}$ & & & \\
\hline Feedback delivery & & & 0.019 & & & & $0.214^{* * *}$ & & & \\
\hline Source availability & & & 0.130 & & & & -0.005 & & & \\
\hline Feedback & & & & $0.411^{* * *}$ & & & & $0.706^{* * *}$ & & \\
\hline Distributive justice & & & & & & & & & $0.181^{* *}$ & \\
\hline Interpersonal justice & & & & & & & & & $0.237^{* *}$ & \\
\hline Informational justice & & & & & & & & & $0.184 *$ & \\
\hline Organisational justice & & & & & & & & & & $0.485^{* * *}$ \\
\hline $\mathrm{R} 2$ & 0.286 & 0.258 & 0.185 & 0.169 & 0.655 & 0.646 & 0.587 & 0.498 & 0.261 & 0.235 \\
\hline Total F & $29.465^{* * *}$ & $103.084^{* * *}$ & $16.690^{* * *}$ & $60.254^{* * *}$ & $139.583 * * *$ & $541.467^{* * *}$ & $104.262 * * *$ & $295.147^{* * *}$ & $25.293^{* * *}$ & $91.247^{* * *}$ \\
\hline Adjusted R2 & 0.276 & 0.255 & 0.174 & 0.166 & 0.650 & 0.645 & 0.581 & 0.497 & 0.251 & 0.232 \\
\hline
\end{tabular}

${ }^{* * *} p<0.01 .{ }^{* *} p<0.05 .{ }^{*} p<0.1$. 
The results (Table 3$)$ indicate that goal rationale $(0.136, p<0.05)$, goal clarity $(0.191$, $p<0.01)$, and organisational facilitation of goal achievement $(0.269, p<0.01)$ are predictors of employee engagement. However, no statistically significant relation has been found between the use of goal setting in performance appraisal and employee engagement. As it was expected, there is a direct link between goal setting and employee engagement $(0.508$, $p<0.001$ ). Thus, the hypotheses H1a, H1b, H1c, and $\mathrm{H} 1$ have been confirmed (no support for H1d).

$\mathrm{H} 2$ suggests a positive relationship between feedback, as a component of performance management, and employee engagement. As it is seen from Column 4 (Engagement $\mathrm{H} 2 \mathrm{a}-$ $\mathrm{H} 2 \mathrm{~d}$ ) and Column 5 (Engagement $\mathrm{H} 2$ ) of Table 3, the results indicate that source credibility $(0.220, p<0.01)$ and feedback quality $(0.157, p<0.05)$ have a positive relationship with work engagement. In cases of feedback delivery and source availability, a statistically significant relation has been found. As it was expected, there is a direct link between feedback and work engagement $(0.411, p<0.001)$. Thus, the hypotheses $\mathrm{H} 2 \mathrm{a}, \mathrm{H} 2 \mathrm{~b}$, and $\mathrm{H} 2$ have been confirmed (no support for $\mathrm{H} 2 \mathrm{c}$ and $\mathrm{H} 2 \mathrm{~d}$ ).

$\mathrm{H} 3$ proposes that goal setting, including goal rationale $(\mathrm{H} 3 \mathrm{a})$, goal clarity $(\mathrm{H} 3 \mathrm{~b})$, organisational facilitation of goal achievement $(\mathrm{H} 3 \mathrm{c})$, and use of goal setting in performance appraisal (H3d) will be positively related to organisational justice. As it is seen from Table 3, all these hypotheses have been confirmed. As regards the hypothesis $\mathrm{H} 4$, only $\mathrm{H} 4 \mathrm{~d}$ has not been confirmed.

$\mathrm{H} 5$ proposes that organisational justice, including distributive (H5a), procedural (H5b), interpersonal $(\mathrm{H} 5 \mathrm{c})$, and informational justice $(\mathrm{H} 5 \mathrm{~d})$, will be positively related to employee engagement. As it is seen from Columns 10 and 11 in Table 3, only procedural justice has not affected employee engagement. Thus, hypotheses $\mathrm{H} 5 \mathrm{a}, \mathrm{H} 5 \mathrm{c}, \mathrm{H} 5 \mathrm{~d}$, and $\mathrm{H} 5$ have been confirmed.

Summary of hypotheses and findings are provided in Appendix B.

Mediating effects of organisational justice. According to Baron and Kenny (1986), three conditions must be met to establish mediation. First, the independent variable (in this paper-goal setting and feedback) must be related to the mediator (in this paperorganisational justice). Second, the mediator (in this paper-organisational justice) must be related to the dependent variable (in this paper-employee engagement). Third, a significant relationship between the independent variable (goal setting and feedback) and the dependent variable (work engagement) will be reduced (partial mediation) or be no longer significant (full mediation) when controlling for the mediator (organisational justice).

In order to test the mediation model in which organisational justice mediates the relationship between the goal setting and employee engagement and feedback and employee engagement, additional regression analyses were conducted (Table 4).

Table 4. Mediating effects of organisational justice.

\begin{tabular}{lll}
\hline \multicolumn{1}{c}{$\mathbf{1}$} & \multicolumn{1}{c}{$\mathbf{2}$} & \multicolumn{1}{c}{3} \\
\hline & Engagement H6 & Engagement H7 \\
Goal setting & $0.333^{* * *}$ & \\
Organisational justice & $0.217^{* *}$ & 0.136 \\
\hline Feedback & & $0.388^{* * *}$ \\
Organisational justice & & 0.244 \\
\hline R2 & 0.274 & $47.859^{* * *}$ \\
Total F & $55.953^{* * *}$ & 0.239 \\
Adjusted R2 & $0.269^{* *}$ & \\
\hline
\end{tabular}

${ }^{* * *} p<0.001,{ }^{* *} p<0.01$.

As is it seen from Table 3 (Column 3) and Table 4 (Column 2), the addition of organisational justice to the equation has increased the variance explained from $25 \%$ to $26 \%$, and the goal setting is further statistically significant at the $p<0.001$ level, indicating a partial 
mediation relationship. Thus, hypothesis $\mathrm{H} 6$ has been partly confirmed-organisational justice partially mediates the linkage between goal setting and work engagement.

The situation is different in case of feedback. As is it seen from Table 3 (Column 5 ) and Table 4 (Column 3), the addition of organisational justice to the equation has increased the variance explained from $16 \%$ to $23 \%$, and the feedback is no longer statistically significant, indicating a full mediation relationship. Thus, hypothesis $\mathrm{H} 7$ has been confirmed-organisational justice fully mediates the linkage between feedback and work engagement.

As it was mentioned before, the results provide support for most of the hypotheses. Further, interpretations of some findings are provided considering the existing theoretical insights and empirical studies.

Turning to hypothesis $\mathrm{H1}$, the findings revealed that goal setting served as a determinant of work engagement. More specifically, employee understanding why some goals are set for them (goal rationale), goal clarity, and organisational support for goal achievement led to higher work engagement. Such findings could be interpreted having SET in mind. As it was mentioned before, SET posits that in interdependent relationships, transactions between parties rely mainly on reciprocity rules (Cropanzano and Mitchell 2005). The reciprocity norm specifies that favourable treatment received by one party obligates another party to provide favourable treatment in return. On the other hand, when negative treatment is demonstrated, lower attitude or poor behaviour would be reciprocated (Huang et al. 2016). In case of the current research, work engagement can be interpreted as the positive employee response to the exchange for goal clarity, rationality, and facilitation while achieving goals (Cropanzano and Mitchell 2005). One more point that needs attention, especially from the practical research relevance point of view, is related to clarity and ambiguity of terms and processes in general. According to Andrews and Mostafa (2019), the more difficult it is to interpret the goals, the more likely it is that employees will misunderstand and misdirect their efforts towards unproductive or unimportant work activities, and this in turn may lower work engagement. A study of 4000 senior public managers in 10 European countries demonstrated that there was a negative relationship between goal ambiguity and engagement, i.e., ambiguous organisational goals may place demands on senior managers that weaken their engagement (Andrews and Mostafa 2019).

Turning to hypothesis $\mathrm{H} 2$, the findings revealed that feedback drove work engagement. Generally, feedback is often considered as a key element of performance management (Teeroovengadum et al. 2019). It is indispensable in the daily supervisor-to-subordinate exchange process as information delivered via feedback can inform the employees of how well they are achieving their performance goals (Steelman et al. 2004; Guo and Ling 2020). The findings could be interpreted having the COR theory in mind. Following the COR theory (Salanova et al. 2010), feedback is one of job resources that stimulates personal growth and development, and initiates a motivational process that in turn leads to work engagement, as was the case in the current research. The findings are in line with the results of a study by Xanthopoulou et al. (2009), which revealed that employees who received feedback were more likely to be vigorous, dedicated, and absorbed in their work tasks over the course of time.

As it was mentioned before, the findings demonstrated that feedback quality predicted work engagement $(\mathrm{H} 2 \mathrm{~b})$. Feedback quality refers to consistency and usefulness of a feedback message (Steelman et al. 2004). There seems to be a consensus in the literature arguing that feedback quality provides information that can improve employee attitudes, behaviours, and performance (Blackman et al. 2012; Guo and Ling 2020). Thus, the current results reflect the common notion in the earlier literature as regards feedback quality and work engagement linkage.

As it was anticipated by hypothesis $\mathrm{H} 3$, goal setting, including all four aspects, served as a driver for organisational justice. Understanding how people make judgments about justice in their organisations is a major issue, especially developing an understanding of organisational behaviour (Maleki and Taheri 2012). Diefenbach (2009) argues that perfor- 
mance management in the public sector, when it is based on explicit targets, standards, performance indicators, measurement, and control systems, makes it possible to rely more on 'facts' and have a rational basis. Such ambition is related to organisational justice as it is concerned with "the ways in which employees determine if they have been treated fairly in their jobs" (Moorman 1991, p. 845). Consequently, having a clear formulation and prioritisation of goals (goal clarity), having an understanding why some goals are set (goal rationale), receiving time, financial or human support for proper goal execution (facilitation of goal achievement), and using goals for performance appraisal create a feeling for justice among the public sector employees.

In case of hypothesis H4, feedback, including source credibility, feedback quality, and feedback delivery, had a potential to predict increased work engagement. In case of source availability $(\mathrm{H} 4 \mathrm{~d})$, no statistically significant relationship was found. There are no doubts that feedback is needed to improve performance (Kingsley Westerman et al. 2018). However, to start improving their performance employees must believe that the deliverer of the information is a credible source (Kingsley Westerman et al. 2018). Further, feedback requires quality, i.e., usefulness and consistency of the message. Next, the extent to which feedback delivery is tactful and considerate is also highly important. Relying on the current research results, when employees perceive feedback as credible, high quality, and tactful, their perception of organisational justice increases.

Generally, organisational justice is a very important aspect in social interactions as drawing upon SET (Blau 1964) the social exchange is based on equity exchange (CugueróEscofet et al. 2019). The findings allow for concluding that when employees have higher perception of justice in a public organisation, they are also more likely to feel obliged to give more of themselves through greater levels of engagement (Cropanzano and Mitchell 2005). Such a conclusion might be reinforced by previous research. For instance, the survey of 210 employees of public sector banks in India revealed that distributive, procedural, and interactional justice predicted work engagement (Ghosh et al. 2014). Özer et al. (2017) found that rising organisational justice perception statistically increased employee work engagement in the health care sector. Thus, the present research supported the message that organisational justice was an important predictor of positive work attitudes of employees, including work engagement (Greenberg 1990; Choi 2011; Mylona and Mihail 2019; Farndale et al. 2011) dominating in earlier studies.

\section{Conclusions}

The paper aimed at exploring the relationship between leaders' behaviour in performance management, work engagement, and organisational justice in the public sector. The findings revealed that goal setting and feedback, as two components of performance management, impacted the work engagement in the public sector. Moreover, such an impact was mediated by organisational justice.

The paper provides several practical implications for leaders and human resource management practitioners. The empirical results of this research support the idea that the public sector cannot deny the role of performance management treating it as a less important human resource management aspect (Aguinis 2014). In line with the findings, goals should be set and feedback should be provided to employees in an appropriate manner as performance management promotes both work engagement and organisational justice. Goals for employees working in the public sector should be rational and clear. Moreover, goal achievement should be facilitated by various means in terms of time, co-workers, equipment, or money. Finally, goals should be discussed during performance appraisal. Turning to feedback, source credibility is of high importance, implying that managers (feedback source) are obliged to have knowledge of employees' actual performance on the job and job requirements as well as the ability to accurately judge the performance of each job. Source credibility increases when employees trust the manager to possess accurate performance information. Feedback quality goes up when feedback is consistent across time, specific, and useful. Feedback delivery with respect to employee and manager being 
available for feedback are also important parts of feedback the manager cannot ignore. Summing up, a well-executed goal setting and feedback can be beneficial for the public sector by increasing organisational justice and work engagement.

Actually, while seeking to be more effective, organisational justice and work engagement are highly relevant for the public sector as they lead to different employee behaviours in terms of delivering service quality, behaviour with citizens, or even leaving the organization. For instance, employees, depending on their justice perceptions, are likely to behave in different ways. As stated by Özer et al. (2017), when "employees perceive distributive injustice they react against the results of the decisions taken by the organization; if they perceive procedural injustice they may react against the entire organization; when they perceive interactional injustice they may react against their administrators" (p. 78). Such behaviours are not beneficial for the public sector and need to be managed. Following the results of the current research, one of such management tools refers to performance management, including goal setting and feedback.

The paper has several limitations to consider when interpreting the mentioned findings. The paper uses a sample only from the employees working in the public sector. Due to this fact, there is no possibility to compare the situation in the public sector in terms of leaders' behaviour in performance management, organisational justice, and work engagement with the situation in private business. Thus, further research could be conducted including both private and public settings.

Further, the paper uses a sample from a single country; it has a limitation due to its restrictive generalizability. In order to overcome this, future research could be extended to a whole region. Moreover, as the paper incorporates two components of performance management, future research could include more components, for instance performance monitoring.

In conclusion, this paper challenges the researchers and managers to move towards more sophisticated assessments as to how and why performance management affects the employee attitudes and behaviour, which might lead to better organisational performance.

Author Contributions: All authors contributed equally. All authors have read and agreed to the published version of the manuscript.

Funding: This research received no external funding.

Institutional Review Board Statement: Not applicable.

Informed Consent Statement: Not applicable.

Data Availability Statement: Not applicable.

Conflicts of Interest: The authors declare no conflict of interest.

\section{Appendix A. Survey Items}

Goal rationale (Lee et al. 1991):

1. My boss tells me the reasons for giving me the goals I have.

2. My boss clearly explains to me what my goals are.

3. I understand how my performance is measured on this job.

4. I get regular feedback indicating how I am performing in relation to my goals. Goal clarity (Lee et al. 1991):

1. I understand exactly what I am supposed to do in my job.

2. I have specific, clear goals to aim for on my job.

3. If I have more than one goal to accomplish, I know which ones are most important and which are least important.

4. The other people I work with encourage me to attain my goals.

Organisational facilitation of goal achievement (Lee et al. 1991): 
1. This organisation provides sufficient resources (time, money, co-workers, equipment) to make the goal setting work.

2. The goals I have on this job are challenging but reasonable (neither too hard nor too easy).

3. Organisation policies here help rather than hurt goal attainment.

4. Work team in this organization work together to attain goals.

5. During performance appraisal interviews, my boss schedules a follow-up meeting so that we can discuss progress in relation to the goals.

Use of goal setting in performance appraisal (Lee et al. 1991):

1. In performance appraisal sessions with my boss, he stresses problem-solving rather than criticism.

2. During performance appraisal interviews, my boss:

(2a) explains the purpose of the meeting to me

(2b) asks me to tell him/her what I have done that deserves recognition

(2c) asks me if there are any areas of the job on which he or she can assist me

(2d) tells me what he or she thinks I have done that deserves recognition

(2e) if there are any problems with my performance, never brings up more than two of them at once

(2f) listens openly to my explanations and concerns regarding any performance problems

(2g) comes to agreement with me on steps to be taken be each of us to solve any performance problems

(2h) makes sure that at the end of the interview I have a specific goals or goals in mind I am to achieve in the future

Source credibility (Steelman et al. 2004):

5. My supervisor is generally familiar with my performance on the job.

6. In general, I respect my supervisor's opinions about my job performance.

7. With respect to job performance feedback, I usually do not trust my supervisor (R).

8. My supervisor is fair when evaluating my job performance.

9. I have confidence in the feedback my supervisor gives me.

Feedback quality (Steelman et al. 2004):

1. The performance feedback I receive from my supervisor is helpful.

2. My supervisor gives me useful feedback about my job performance.

3. I value the feedback I receive from my supervisor.

4. The feedback I receive from my supervisor helps me do my job.

5. The performance information I receive from my supervisor is generally not very meaningful (R).

Feedback delivery (Steelman et al. 2004):

1. My supervisor is tactful when giving me performance feedback.

2. My supervisor is supportive when giving me feedback about my job performance.

3. When my supervisor gives me performance feedback, he or she is considerate of my feelings.

4. My supervisor generally provides feedback in a thoughtless manner.

5. My supervisor does not treat people very well when providing performance feedback (R).

Source availability (Steelman et al. 2004):

1. My supervisor is too busy to give me feedback (R).

2. My supervisor is usually available when I want performance information.

3. I have little contact with my supervisor (R).

4. I interact with my supervisor on a daily basis.

5. The only time I receive performance feedback from my supervisor is during my performance review $(\mathrm{R})$. 
Work engagement (Schaufeli et al. 2006):

1. At my work, I feel bursting with energy.

2. I find the work that I do full of meaning and purpose.

3. Time flies when I am working.

4. At my job, I feel strong and vigorous.

5. I am enthusiastic about my job.

6. When I am working, I forget everything else around me.

7. My job inspires me.

8. When I get up in the morning, I feel like going to work.

9. I feel happy when I am working intensely.

10. I am proud of the work that I do.

11. I am immersed in my work.

12. I can continue working for very long periods at a time.

13. To me, my job is challenging.

14. I get carried away when I am working.

15. At my job, I am very resilient, mentally.

16. It is difficult to detach myself from my job.

17. At my work, I always persevere, even when things do not go well.

Organisational justice (Colquitt et al. 2001):

Procedural Justice. To what extent 1 . Have you been able to express your views and feelings during performance management procedures? 2. Have you had influence over the outcome arrived by performance management procedures? 3. Have performance management procedures been applied consistently? 4. Have performance management procedures been free of bias? 5 . Have performance management procedures been based on accurate information? 6. Have you been able to appeal the outcome arrived at by performance management procedures? 7. Have performance management procedures upheld ethical and moral standards?

Distributive Justice. To what extent 1 . Does your (outcome) reflect the effort you have put into your work? 2. Is your (outcome) appropriate for the work you have completed? 3. Does your (outcome) reflect what you have contributed to the organization? 4. Is your (outcome) justified, given your performance?

Interpersonal Justice. To what extent 1 . Has your line manager treated you in a polite manner? 2. Has your line manager treated you with dignity? 3. Has your line manager treated you with respect? 4. Has your line manager refrained from improper remarks or comments?

Informational Justice. To what extent 1 . Has your line manager been candid in his/her communications with you? 2. Has your line manager explained the procedures thoroughly? 3. Were line mangers' explanations regarding the procedures reasonable? 4. Has your line manager communicated details in a timely manner? 5 . Has your line manager seemed to tailor his/her communications to individuals' specific needs? 


\section{Appendix B. Summary of Hypotheses and Findings}

Table A1. Summary of hypotheses and findings.

Hypothesis
H1. Goal setting will be positively related to employee
engagement.

H1a. Goal rationale will be positively related to employee engagement

H1b. Goal clarity will be positively related to employee engagement.

H1c. Organisational facilitation of goal achievement will be positively related to employee engagement.

H1d. Use of goal setting in performance appraisal will be positively related to employee engagement.

H2. Feedback will be positively related to employee engagement.

H2a. Source credibility will be positively related to employee engagement.

$\mathbf{H} \mathbf{2 b}$. Feedback quality will be positively related to employee engagement.

H2c. Feedback delivery will be positively related to employee engagement.

$\mathbf{H} 2 d$. Source availability will be positively related to employee engagement.

H3. Goal setting will be positively related to organisational justice.

H3a. Goal rationale will be positively related to organisational justice.

H3b. Goal clarity will be positively related to organisational justice.

H3c. Organisational facilitation of goal achievement will be positively related to organisational justice.

H3d. Use of goal setting in performance appraisal will be positively related to organisational justice.

H4. Feedback will be positively related to organisational justice.

H4a. Source credibility will be positively related to organisational justice.

H4b. Feedback quality will be positively related to organisational justice.

H4c. Feedback delivery will be positively related to organisational justice.

H4d. Source availability will be positively related to organisational justice.

H5. Organisational justice will be positively related to employee engagement.

H5a. Distributive justice will be positively related to employee engagement.

H5b. Procedural justice will be positively related to employee engagement.

H5c. Interpersonal justice will be positively related to employee engagement.

H5d. Informational justice will be positively related to employee engagement.

H6. Organisational justice will mediate the relationship between goal setting and employee engagement.

H7. Organisational justice will mediate the relationship between feedback and employee engagement.

Relationships Findings

Positive

Supported

Positive

Supported

Positive

Supported

Positive

Supported

No relationship

Positive

Supported

Positive

Supported

Positive

Supported

No relationship

No relationship

Positive

Supported

Positive

Supported

Positive

Supported

Positive

Supported

Positive

Supported

Positive

Supported

Positive

Supported

Positive

Supported

Positive

Supported

No relationship

Positive

Supported

Positive

Supported

No relationship

Positive

Supported

Positive

Supported

Partly confirmed

Confirmed 


\section{References}

Aguinis, Herman. 2014. Performance Management. London: Pearson.

Aguinis, Herman, and Charles A. Pierce. 2008. Enhancing the relevance of organizational behavior by embracing performance management research. Journal of Organizational Behavior: The International Journal of Industrial, Occupational and Organizational Psychology and Behavior 29: 139-45. [CrossRef]

Aguinis, Herman, Harry Joo, and Ryan K. Gottfredson. 2011. Why we hate performance management-And why we should love it. Business Horizons 54: 503-7. [CrossRef]

Alfes, Kerstin, A. D. Shantz, C. Truss, and E. C. Soane. 2013. The link between perceived human resource management practices, engagement and employee behaviour: A moderated mediation model. The International Journal of Human Resource Management 24: 330-51. [CrossRef]

Ancarani, Alessando, Carmela Di Mauro, Maria Daniela Giammanco, and Giuseppe Giammanco. 2018. Work engagement in public hospitals: A social exchange approach. International Review of Public Administration 23: 1-19. [CrossRef]

Ander, Steve, and Art Swift. 2014. US Federal Employees Less Engaged than the Rest. December 16. Available online: http: / / www.gallup.com/poll/180206/federal-employeesless-engaged-rest.aspx (accessed on 12 January 2021).

Andrews, Rhys, and Ahmed Mohammed Sayed Mostafa. 2019. Organizational goal ambiguity and senior public managers' engagement: Does organizational social capital make a difference? International Review of Administrative Sciences 85: 377-95. [CrossRef]

Armstrong. 2018. Armstrong's Handbook of Performance Management. An Evidence-Based Guide to Delivering High Performance. London: Kogan Page, p. 256.

Awan, Sajid Hussain, Nazia Habib, Chaudhry Shoaib Akhtar, and Shaheryar Naveed. 2020. Effectiveness of Performance Management System for Employee Performance through Engagement. SAGE Open 10: 2158244020969383. [CrossRef]

Banfield, Paul, and Rebecca Kay. 2012. Introduction to Human Resource Management, 2nd ed. New York: Oxford University Press.

Baron, Reuben M., and David A. Kenny. 1986. The moderator-mediator variable distinction in social psychological research: Conceptual, strategic and statistical considerations. Journal of Personality and Social Psychology 51: 1173-82. [CrossRef] [PubMed]

Becker, Karen, Nicholas Antuar, and Cherie Everett. 2011. Implementing an employee performance management system in a nonprofit organization. Nonprofit Management and Leadership 21: 255-71. [CrossRef]

Biswas, Soumendu, Arup Varma, and Aarti Ramaswami. 2013. Linking distributive and procedural justice to employee engagement through social exchange: A field study in India. The International Journal of Human Resource Management 24: 1570-87. [CrossRef]

Blackman, Deborah Ann, Fiona Buick, Michael O'Donnell, Janine L. O'Flynn, and Damian West. 2012. Developing High Performance: Performance Management in the Australian Public Service. Crawford School Research Paper No. 12-09. Canberra: Crawford School, Available online: https:/ / ssrn.com/abstract=2130232 (accessed on 28 January 2021).

Blau, Peter Michael. 1964. Exchange and Power in Social Life. New York: John Wiley.

Buchner, Thomas W. 2007. Performance management theory: A look from the performer's perspective with implications for HRD. Human Resource Development International 10: 59-73. [CrossRef]

Buick, Fiona, Deborah Ann Blackman, Michael E. O'Donnell, Janine L. O'Flynn, and Damian West. 2015. Can enhanced performance management support public sector change? Journal of Organizational Change Management. [CrossRef]

Choi, Sungjoo. 2011. Organizational justice and employee work attitudes: The federal case. The American Review of Public Administration 41: 185-204. [CrossRef]

Christian, Michael S., Adela S. Garza, and Jerel E. Slaughter. 2011. Work engagement: A quantitative review and test of its relations with task and contextual performance. Personnel Psychology 64: 89-136. [CrossRef]

Claus, Lisbeth, and Dennis Briscoe. 2009. Employee performance management across borders: A review of relevant academic literature. International Journal of Management Reviews 11: 175-96. [CrossRef]

Colquitt, Jason A., Donald E. Conlon, Michael J. Wesson, Christoper O. Porter, and K. Yee Ng. 2001. Justice at the millennium: A meta-analytic review of 25 years of organizatioanl justice research. Journal of Applied Psychology 86: 424-24. [CrossRef] [PubMed]

Cook, Karen S., Coye Cheshire, Eric R. Rice, and Sandra Nakagawa. 2013. Social exchange theory. In Handbook of Social Psychology. Dordrecht: Springer, pp. 61-88.

Cropanzano, Russell, and Marie S. Mitchell. 2005. Social exchange theory: An interdisciplinary review. Journal of Management 31: 874-900. [CrossRef]

Cropanzano, Ruseell, David E. Bowen, and Stephen W. Gilliland. 2007. The management of organizational justice. Academy of Management Perspectives 21: 34-48. [CrossRef]

Cugueró-Escofet, Natàlia, Pilar Ficapal-Cusí, and Joan Torrent-Sellens. 2019. Sustainable human resource management: How to create a knowledge sharing behavior through organizational justice, organizational support, satisfaction and commitment. Sustainability 11: 5419. [CrossRef]

Dahling, Jason J., Allison S. Gabriel, and Rebecca MacGowan. 2017. Understanding typologies of feedback environment perceptions: A latent profile investigation. Journal of Vocational Behavior 101: 133-48. [CrossRef]

De Vries, Michiel, and Jural Nemec. 2013. Public sector reform: An overview of recent literature and research on NPM and alternative paths. International Journal of Public Sector Management. [CrossRef]

Diefenbach, Thomas. 2009. New public management in public sector organizations: The dark sides of managerialistic 'enlightenment'. Public Administration 87: 892-909. [CrossRef] 
Elicker, Joelle D., Mark Cubrich, Julie M. Chen, Mary F. Sully de Luque, and Rachel Gabel Shemueli. 2019. Employee reactions to the feedback environment. In Feedback at Work. Cham: Springer, pp. 175-194.

Etikan, Ilker, Sulaiman Abubakar Musa, and Rukayya Sunusi Alkassim. 2016. Comparison of convenience sampling and purposive sampling. American Journal of Theoretical and Applied Statistics 5: 1-4. [CrossRef]

Tahir Farid, Sadaf Iqbal, Jianhong Ma, Sandra Castro-González, Amira Khattak, and Muhammad Khalil Khan. 2019. Employees' perceptions of CSR, work engagement, and organizational citizenship behavior: The mediating effects of organizational justice. International Journal of Environmental Research and Public Health 16: 1731. [CrossRef]

Farndale, Elaine, Veronica Hope-Hailey, and Clare Kelliher. 2011. High commitment performance management: The roles of justice and trust. Personnel Review 40: 5-23. [CrossRef]

Gallup. 2017. State of the Global Workplace. New York: Gallup Press.

Ghosh, Piyali, Alka Rai, and Apsha Sinha. 2014. Organizational justice and employee engagement. Personnel Review 43: 628-52. [CrossRef]

Greenberg, Jerald. 1990. Organizational justice: Yesterday, today, and tomorrow. Journal of Management 16: 399-432. [CrossRef]

Gruman, Jamie A., and Alan M. Saks. 2011. Performance management and employee engagement. Human Resource Management Review 21: 123-36. [CrossRef]

Guo, Yue, and Bin Ling. 2020. Effects of leader motivating language on employee task and contextual performance: The mediating role of feedback quality. Psychological Reports 123: 2501-18. [CrossRef] [PubMed]

Hobfoll, Stevan E. 1989. Conservation of resources: A new attempt at conceptualizing stress. American Psychologist 44: 513. [CrossRef]

Hood, Christopher. 1991. A public management for all seasons? Public Administration 69: 3-19. [CrossRef]

Hood, Christopher. 1995. The "new public management" in the 1980s: Variations on a theme. Accounting, Organizations and Society 20: 93-109. [CrossRef]

Huang, Yueng-Hsiang, Jin Lee, Anna C. McFadden, Lauren A. Murphy, Michelle M. Robertson, Janelle H. Cheung, and Dov Zohar. 2016. Beyond safety outcomes: An investigation of the impact of safety climate on job satisfaction, employee engagement and turnover using social exchange theory as the theoretical framework. Applied Ergonomics 55: 248-57. [CrossRef] [PubMed]

Ilgen, Daniel R., Cynthia D. Fisher, and M. Susan Taylor. 1979. Consequences of individual feedback on behavior in organizations. Journal of applied psychology 64: 349. [CrossRef]

Jiang, Kaifeng, David P. Lepak, Jia Hu, and Judith C. Baer. 2012. How does human resource management influence organizational outcomes? A meta-analytic investigation of mediating mechanisms. Academy of Management Journal 55: 1264-94. [CrossRef]

Jung, Chan Su. 2014. Organizational goal ambiguity and job satisfaction in the public sector. Journal of Public Administration Research and Theory 24: 955-81. [CrossRef]

Kashyap, Vishal, Áurea Helena Puga Ribeiro, Anthony Asare, and Thomas G. Brashear. 2007. Developing sales force relationalism: The role of distributive and procedural justice. Journal of Personal Selling \& Sales Management 27: 235-45. [CrossRef]

Kingsley Westerman, Catherine Y., Katie M. Reno, and Kyle B. Heuett. 2018. Delivering feedback: Supervisors' source credibility and communication competence. International Journal of Business Communication 55: 526-46. [CrossRef]

Kluger, Avraham N., and Angelo DeNisi. 1996. The effects of feedback interventions on performance: A historical review, a meta-analysis, and a preliminary feedback intervention theory. Psychological Bulletin 119: 254. [CrossRef]

Latham, Gary P., and Edwin A. Locke. 1991. Self-regulation through goal setting. Organizational Behavior and Human Decision Processes 50: 212-47. [CrossRef]

Latham, Gary P., Joan Almost, Sara Mann, and Celia Moore. 2005. New developments in performance management. Organizational Dynamics 34: 77-87. [CrossRef]

Lee, Cynthia, Philip Bobko, P. Christopher Earley, and Edwin A. Locke. 1991. An empirical analysis of a goal setting questionnaire. Journal of Organizational Behavior 12: 467-82. [CrossRef]

Lietuvos Respublikos Vidaus Reikalu Ministerija. 2020. Viešojo Sektoriaus Ataskaita 2016-2019 m. Vilnius: Lietuvos Respublikos Vidaus Reikalu Ministerija.

Liobikienè, Genovaitè, Julius Liobikas, Janis Brizga, and Romualdas Juknys. 2020. Materialistic values impact on pro-environmental behavior: The case of transition country as Lithuania. Journal of Cleaner Production 244: 118859. [CrossRef]

Locke, Edwin A., and Gary P. Latham. 1990. A Theory of Goal Setting \& Task Performance. Upper Saddle River: Prentice-Hall, Inc.

Locke, Edwin A., and Gary P. Latham. 2002. Building a practically useful theory of goal setting and task motivation: A 35-year odyssey. American Psychologist 57: 705. [CrossRef]

Locke, Edwin A., and Gary P. Latham. 2020. Building a theory by induction: The example of goal setting theory. Organizational Psychology Review 10: 223-39. [CrossRef]

Lynn, Laurence E., Jr. 1998. The new public management: How to transform a theme into a legacy. Public Administration Review 58: 231-37. [CrossRef]

Maleki, Hamid, and Leila Mir Taheri. 2012. Organizational justice: From theory to practice. Journal of Basic and Applied Scientific Research 2: 10118-23.

Mann, Annamarie, and Jim Harter. 2016. The worldwide employee engagement crisis. Gallup Business Journal 7: 1-5.

Maslach, Christina, and Michael P. Leiter. 2008. Early predictors of job burnout and engagement. Journal of Applied Psychology 93: 498. [CrossRef] [PubMed] 
Moliner, Carolina, Vincente Martinez-Tur, José Ramos, José M. Peiró, and Russell Cropanzano. 2008. Organizational justice and extrarole customer service: The mediating role of well-being at work. European Journal of Work and Organizational Psychology 17: 327-48. [CrossRef]

Moorman, Robert H. 1991. Relationship between organizational justice and organizational citizenship behaviors: Do fairness perceptions influence employee citizenship? Journal of Applied Psychology 76: 845. [CrossRef]

Mostafa, Ahmed Mohammed Sayed, and Eman Aly Abed El-Motalib. 2020. Ethical leadership, work meaningfulness, and work engagement in the public sector. Review of Public Personnel Administration 40: 112-31. [CrossRef]

Mylona, Evangelia, and Dimitrios Mihail. 2019. Enhancing Employees' Work Performance through Organizational Justice in the Context of Financial Crisis. A Study of the Greek Public Sector. International Journal of Public Administration 42: 509-19. [CrossRef]

Nakrošis, Vitalis. 2018a. Public Administration Characteristics and Performance in EU28: Lithuania. Luxembourg: Publications Office of the European Union.

Nakrošis, Vitalis. 2018b. The Agendas of Public Administration Reforms in Lithuania: Windows of Opportunity in the Period 2004-2017. NISPAcee Journal of Public Administration and Policy 11: 91-114. [CrossRef]

Norris-Watts, C., and P. E. Levy. 2004. The mediating role of affective commitment in the relation of the feedback environment to work outcomes. Journal of Vocational Behavior 65: 351-65. [CrossRef]

Nunnally, Jum C. 1978. Psychometric Theory, 2nd ed. Hillsdale: McGraw-Hill, p. 416.

Orazi, Davide Christian, Alex Turrini, and Giovanni Valott. 2013. Public sector leadership: New perspectives for research and practice. International Review of Administrative Sciences 79: 486-504. [CrossRef]

Osborne, D., and Ted Gaebler. 1992. Reinventing Government. Reading: Addison Wesley.

Özer, Özlem, Özgür Uğurluoğlu, and Meltem Saygi. 2017. Effect of organizational justice on work engagement in healthcare sector of Turkey. Journal of Health Management 19: 73-83. [CrossRef]

Paauwe, Jaap. 2009. HRM and performance: Achievements, methodological issues and prospects. Journal of Management Studies 46: 129-42. [CrossRef]

Pulakos, Elaine D. 2009. Performance Management: A New Approach for Driving Business Results. Malden: Wiley-Blackwell.

Raipa, Alvydas, and Vidmante Giedraityte. 2014. Innovation process barriers in public sector: A comparative analysis in Lithuania and the European Union. International Journal of Business and Management 9: 10. [CrossRef]

Rosen, Christopher C., Paul E. Levy, and Rosalie J. Hall. 2006. Placing perceptions of politics in the context of the feedback environment, employee attitudes, and job performance. Journal of Applied Psychology 91: 211. [CrossRef] [PubMed]

Rubin, Ellen V. 2009. The role of procedural justice in public personnel management: Empirical results from the Department of Defense. Journal of Public Administration Research and Theory 19: 125-43. [CrossRef]

Saks, Alan M. 2006. Antecedents and consequences of employee engagement. Journal of Managerial Psychology 21: 600-19. [CrossRef]

Salanova, Marisa, Wilmar B. Schaufeli, Despoina Xanthopoulou, and Arnold B. Bakker. 2010. The gain spiral of resources and work engagement: Sustaining a positive worklife. In Work Engagement: A Handbook of Essential Theory and Research. East Sussex: Psychology Press, pp. 118-31. ISBN 978-1-84169-736-9.

Schaufeli, Wilmar B., Marisa Salanova, Vincente González-Romá, and Arnold B. Bakker. 2002. The measurement of engagement and burnout: A two sample confirmatory factor analytic approach. Journal of Happiness Studies 3: 71-92. [CrossRef]

Schaufeli, Wilmar B., Arnold B. Bakker, and Marisa Salanova. 2006. The measurement of work engagement with a short questionnaire: A cross-national study. Educational and Psychological Measurement 66: 701-16. [CrossRef]

Schwarz, Gary, Nathan Eva, and Alexander Newman. 2020. Can Public Leadership Increase Public Service Motivation and Job Performance? Public Administration Review 80: 543-54. [CrossRef]

Steelman, Lisa A., Paul E. Levy, and Andrea F. Snell. 2004. The feedback environment scale: Construct definition, measurement, and validation. Educational and Psychological Measurement 64: 165-84. [CrossRef]

Teeroovengadum, Viraiyan, Robin Nunkoo, and Humaira Dulloo. 2019. Influence of organisational factors on the effectiveness of performance management systems in the public sector. European Business Review. [CrossRef]

Van der Hoek, Marieke, Sandra Groeneveld, and Ben Kuipers. 2018. Goal setting in teams: Goal clarity and team performance in the public sector. Review of Public Personnel Administration 38: 472-93. [CrossRef]

Van Waeyenberg, Thomas, Adelien Decramer, Sebastian Desmidt, and Mieke Audenaert. 2017. The relationship between employee performance management and civil servants' turnover intentions: A test of the mediating roles of system satisfaction and affective commitment. Public Management Review 19: 747-64. [CrossRef]

Viešojo Sektoriaus Pokyčiai: Mažeja Darbuotoju ir Organizaciju, o Atlyginimai Auga. 2019. Available online: https://www.delfi.lt/ darbas / darbo-rinka/viesojo-sektoriaus-pokyciai-mazeja-darbuotoju-ir-organizaciju-o-atlyginimai-auga.d?id=81512739 (accessed on 12 January 2020).

West, Damian, and Debor Blackman. 2015. Performance management in the public sector. Australian Journal of Public Administration 74: 73-81. [CrossRef]

Xanthopoulou, Despoina, Arnold B. Bakker, Evangelia Demerouti, and Wilmar B. Schaufeli. 2009. Reciprocal relationships between job resources, personal resources, and work engagement. Journal of Vocational Behavior 74: 235-44. [CrossRef]

Yearta, Shawn K., Sally Maitlis, and Rob B. Briner. 1995. An exploratory study of goal setting in theory and practice: A motivational technique that works? Journal of Occupational and Organizational Psychology 68: 237-52. [CrossRef] 
Young, Stephen F., and Lisa A. Steelman. 2014. The role of feedback in supervisor and workgroup identification. Personnel Review. [CrossRef]

Zhang, Xinggui, Zhibin Lin, Yizhu Liu, Xiao Chen, and David Ming Liu. 2020. How do human resource management practices affect employee well-being? A mediated moderation model. Employee Relations: The International Journal. [CrossRef]

Zhao, Li, and Brian Detlor. 2021. Towards a contingency model of knowledge sharing: Interaction between social capital and social exchange theories. Knowledge Management Research \& Practice, 1-13. [CrossRef] 